\title{
Recent Review on Biogas Production from Different Waste
}

\author{
A.J. Dere*, S.R. Kalbande and V.P. Khambalkar \\ College of Agricultural Engineering \& Technology, Dr. PDKV, Akola, MS - 444 104, India \\ *Corresponding author
}

\section{A B S T R A C T}

Keywords

Biogas production,

Waste,

Composition.

Article Info

Accepted:

28 September 2017

Available Online:

10 October 2017
The focus of the research paper is the production of biogas from various feed stock and different waste. Feedstock composition is one of the major factors that affect the production of biogas. High yields of methane depend mainly on the substrates used as feeding material. However, the difference in total methane yield varies based on the type of interactions between different wastes that interfere with digestibility of wastes in the system. In this study percentage of methane content (the main constituent) in biogas produced from different fermentable materials is almost the same. In this paper the reviews on biogas production from different waste is studied and the different authors suggested that the poultry wastes produced more biogas than poultry droppings. The study revealed that cotton wastes can be treated an aerobically and are a good source of biogas. Kitchen waste has high calorific value and nutritive value to microbes due to which efficiency of methane production can be increased by several orders of magnitude.

\section{Introduction}

Increase in energy demand and the issues about current non-renewable energy resources led researchers to investigate alternative energy sources during the last two decades. Renewable energy resources draw attention all over the world because they are sustainable, improve the environmental quality and provide new job opportunities in rural areas.

Anaerobic digestion (AD) is historically one of the oldest processing technologies used by mankind. Until the 1970s, it was commonly used only in the wastewater treatment plants waste management. The anaerobic digestion is a biological degradation of organic matter by bacteriological flora in anaerobic mode. One such resource is the waste organic matter that is generated in the kitchens and one of the natural agencies which will play an important role in this utilisation is the tiny part of the huge world of tiny microbes. Anaerobic digestion has been considered as waste-toenergy technology, and is widely used in the treatment of different organic wastes, for example: organic fraction of municipal solid waste, sewage sludge, food waste, fish waste, animal manure, etc.

Biogas is a clean renewable energy produced from organic wastes using anaerobic digestion as a method. The products of the digestion are biogas and residue. Biogas is a mixture of methane (CH4) with percentage over than $65 \%$ and carbon dioxide $\left(\mathrm{CO}_{2}\right) . \mathrm{CH} 4$ is the highest component of natural gas. Methane is 
the main combustible gas in biogas. The biogas is useful as a fuel substitute for firewood, dung, agricultural residues, petrol, diesel, and electricity, depending on the nature of the task, and local supply conditions and constraints, thus supplying energy for cooking and lighting. Biogas systems also provide a residue organic waste, after anaerobic digestion that has superior nutrient qualities over the usual organic fertilizer, cattle dung, as it is in the form of Ammonia.

\section{Literature survey of work carried out by various authors}

\section{Biogas production from cow dung, poultry waste, and water hyacinth}

Md. Forhad et al., (2013) investigated the biogas production from different fermentable materials by a small size model biogas plant. A model of batch type fixed dome biogas plant is designed and constructed for producing about $0.5-1.0 \mathrm{~m}^{3}$ of biogas. The fermentable materials were selected as cow dung, poultry waste and water hyacinth. Biogas from cow dung, poultry waste and water hyacinth was analyzed and compared. It was observed that biogas production from cow dung, poultry waste and water hyacinth is $0.034 \mathrm{~m} 3 / \mathrm{kg}, 0.058 \mathrm{~m}^{3} / \mathrm{kg}$ and $0.014 \mathrm{~m}^{3} / \mathrm{kg}$ respectively. Poultry waste produced maximum gas $0.026 \mathrm{~m}^{3}$ at the 8 th day whereas cow dung and water hyacinth produced maximum gas $0.0263 \mathrm{~m}^{3}$ and $0.012 \mathrm{~m}^{3}$ respectively at the 26th day. Percentage of methane content (the main constituent) in biogas produced from different fermentable materials is almost the same.

Tsunatu et al., (2014) carried out study to determine the kinetics of agricultural wastes biogas production when inoculated with cow dung/poultry droppings under mesophilic conditions with $8 \%$ Total Solids and 55 days retention time. The modified first order kinetic model was developed to access the kinetics of the biodegradation of the digestion process. A plot of $1 / t(\ln (d y t / d t))$ against $1 / t$ from the model gives the rates of substrate biodegradability and removal of the biodegradable fractions of the substrate. The result shows that maize cobs (MC) has the highest short term biodegradability index of 1.5827 while bio-digester $\mathrm{D}(\mathrm{SB})$ has the lowest rate of the biodegradable fractions $(\mathrm{k})$ of -0.302 among all the substrates. Biodigester C (Rice Straw) has the highest yield of biogas with cumulative volume of $692.9 \mathrm{ml}$ and an R2 value of 0.8424 while bio-digester D (Sugarcane Bagasse) has the least of $185.9 \mathrm{ml}$ and an $\mathrm{R} 2$ value of 0.6479 .

Sangeetha et al., (2014) studied the comparison of viability of biogas from poultry waste and the mixture of poultry and fish waste. Fish wastes have great potential as a source of high valued organic carbon for methane production and have high content of ammonia nitrogen. In our study we found that the poultry wastes produced more biogas than poultry droppings.

Here we have co-digested poultry waste and cow dung in the ratio of $3: 2$ and also codigested poultry waste with the mixture of fish waste and cow dung in the ratio of 2:2:1. Here the comparison of biogas production was done using water displacement method. The digesters was in capacity about 20 liters and wastes were fed in to digesters in the different ratio. Biogas was collected in water bottles containing Braine solution of sodium hydroxide and the rise in solution level indicates the amount of biogas produced by anaerobic digestion.

After 2 weeks of digestion results showed that there was significant rise in the Braine solution level indicating the biogas production was high in the mixture of poultry waste, fish waste and cow dung. 


\section{Biogas Production from Kitchen Waste}

Ravi Agrahari and Tiwari (2013) investigated that the kitchen waste is the best alternative for biogas production in a community level biogas plant. It is produced when bacteria degrade organic matter in the absence of air. Biogas contains around 55- 65\% of methane, $30-40 \%$ of carbon dioxide. The calorific value of biogas is appreciably high (around $4700 \mathrm{kcal}$ or $20 \mathrm{MJ}$ at around 55\% methane content). The gas can effectively be utilized for generation of power through a biogas based power- generation system after dewatering and cleaning of the gas. In addition, the slurry produced in the process provides valuable organic manure for farming and sustaining the soil fertility. In this paper, an attempt has been made to test the performance of different ratio of kitchen waste in a metal made portable floating type biogas plant of volume capacity $0.018 \mathrm{~m} 3$ for outdoor climatic condition of New Delhi, India. Each of the biogas plant $30 \mathrm{Kg}$ slurry capacity in batch system for all measurement.

Rama Dhanariya et al., (2014) suggested that much of biodegradable wastes such as kitchen wastes and animal wastes are used to produce Biogas, a powerful greenhouse gas. Anaerobic digestion (AD) is a treatment that composts these wastes in the absence of oxygen, producing a biogas that can be used to generate Heat and Power. Producing renewable energy from our biodegradable wastes helps to tackle the energy crisis. It is effectively a controlled and enclosed version of the anaerobic breakdown of organic wastes which releases methane. AD produces a biogas made up of around 60 per cent methane and 40 per cent carbon dioxide $\left(\mathrm{CO}_{2}\right)$. As well as biogas, AD produces a solid and liquid residue called digestate which can be used as a soil conditioner to fertilise land. The amount of biogas and the quality of digestates obtained will vary according to the feedstock used. More gas will be produced if the feedstock is more liable to decompose.

Vipul Vaid and Shivangi Garg (2013) studied that the biogas is a valuable renewable energy source containing 55\% methane and a sustainable mode of waste disposal. It does not have any geographical limitations nor does it require advanced technology for producing energy, also it is very simple to use and apply but is yet to achieve its true potential. These resources, coupled with new and emerging conversion technologies and appropriate energy policy, can make biogas a powerful addition to the renewable energy landscape. Biogas can help decentralize energy generation and immediate benefit from owning a compact biogas system is the savings in cost as compared to the use of kerosene or LPG for cooking. Biogas systems that take kitchen wastes are 800 times efficient than conventional biogas systems. Kitchen waste has high calorific value and nutritive value to microbes due to which efficiency of methane production can be increased by several orders of magnitude.

Laxman Lama et al., (2012) carried out study at Kathmandu University and focuses on production of biogas as an alternative energy by using biodegradable kitchen wastes of Kathmandu University Premises. The research was conducted on modified ARTI model compact biogas plant of $1 \mathrm{~m} 3$ digester and $0.75 \mathrm{~m}$ gasholder in focusing the management of daily produced biodegradable wastes from households. The maximum methane gas was recorded as $65 \%$ and average maximum carbon dioxide was recorded as $58 \%$. The daily temperature inside the digester was found in the range of (25-340C) and $\mathrm{pH}$ value of the slurry was found in between (6.7-5.48). The average gas production was found to be $173 \mathrm{~L} /$ day. The maximum burning period of the gas was approximately $62 \mathrm{~min} /$ day and average 
burning period was $26 \mathrm{~min} /$ day. In the beginning, the proportion of methane is exceeded by carbon dioxide and then after gradually methane exceeded carbon dioxide and reached 56 on average. The amount of gas produced rate during July is low because of rainy season and increases respectively. Since the daily feeding of $5 \mathrm{~kg}$ dry kitchen waste produce $173 \mathrm{~L}$ of gas per day, per $\mathrm{kg}$ of kitchen waste can produce $35 \mathrm{~L}$ of gas daily. The system will provide an appropriate and most efficient solution to the problem of kitchen waste enabling the recovery of energy from waste.

\section{Biogas production from crops and agriculture residues}

Laboya et al., (2010) investigate the importance of biogas as an alternative energy sources. A survey was done to ascertain the amount of biogas that can be generated from various feed stock. A practical laboratory scale experimental design using agricultural waste was also done to find out the effects of Alkaline $(\mathrm{NaOH})$ on the volume of biogas generated using a mixture of pineapple, plantain and cassava peelings as the feed stock. Results obtained reveal a high volume of gas generated when the operating conditions inside the digester is maintained at moderately alkaline condition. Further findings also reveal that the digester temperature remained within the range of 27 to $35.5^{\circ} \mathrm{C}$ throughout the period of experimentation.

Iscia and Demirerb (2007) shows that the anaerobic treatability and methane generation potential of three different cotton wastes namely, cotton stalks, cotton seed hull and cotton oil cake were determined in batch reactors. In addition, the effects of nutrient and trace metal supplementation were also investigated. To this purpose biochemical methane potential (BMP) experiments were performed for two different waste concentrations, namely 30 and $60 \mathrm{~g} / \mathrm{l}$. The results revealed that cotton wastes can be treated an aerobically and are a good source of biogas. Approximately 65, 86 and $78 \mathrm{ml}$ $\mathrm{CH} 4$ were produced in 23 days from $1 \mathrm{~g}$ of cotton stalks, cotton seed hull and cotton oil cake in the presence of basal medium (BM), respectively. BM supplementation had an important positive effect on the production of biogas.

Nabila Laskri and Nawel Nedjah (2015) carried out study on two different substrates: the biodegradable waste from landfill and sludge from the wastewater treatment plant by natural lagoon. They surveyed the evolution of the degradation of organic matter of both experiments which are carried in a digester with a capacity one liter, sealed. The biogas produced from the anaerobic digestion of the two substrates is flammable with a percentage of $\mathrm{CH}_{4}$ more than 64\%. Comparing the volume of biogas produced during the digestion of the two substrates of digestion we found that the volume collect from the sludge waste is greater than 10 times relative to the volume of biogas produced with organic matter in the landfill. The volume of biogas produced is always a function of the residence time of digestion and the concentration of organic matter in the experiment. The percentage of decrease in COD of the sludge was estimated at $87.3 \%$ and the substrate of the landfill is $82.44 \%$.

Attila Meggyes (2012) suggested that biogas production and utilization methods that are suitable for providing continuous operation of existing biogas plants and also for determining the parameters of establishing biogas plants. Experimental variants (mixtures of liquid pig manure and plant additives) were developed to produce biogas and intensify biogas yield, and then gas engine tests were done for the energy 
utilization. The eco-energy system can be built up by taking into consideration the specific local conditions. It does not require any change or transformation of agricultural structure. The system can be expanded by the utilization of other organic materials, so it supports efficient operation. Furthermore, it can be the pillar of energy independence of rural life, because during the establishing of the eco-energy system, ecological aspects are taken into consideration, which makes this system sustainable. Waste disposal requirements can be integrated, too. We created a complex biogas production and utilization system by developing variants, so that both the energy and the waste disposal goals can be achieved together. This system was presented as an alternative agricultural system for an animal farm.

The average production of biogas from all types of waste is around 60 per cent methane and 40 per cent carbon dioxide $\left(\mathrm{CO}_{2}\right)$. The details are as:-

From cotton wastes the production of biogas $\left(\mathrm{CH}_{4}\right)$ approximately $65 \%$.

From the biodegradable waste from landfill and sludge from the wastewater treatment plant by natural lagoon it is more than $64 \%$.

Biogas containing 55\% methane from waste disposal.

From kitchen waste it is near about $65 \%$ methane content.

This study shows that large amount of biogas can be extracted when poultry waste is mixed with fish waste and cow dung.

In this study the percentage of methane content (the main constituent) in biogas produced from different fermentable materials is almost the same. In this study we found that the poultry wastes produce more biogas than other waste.

In this review study it has been found that anaerobic digestion is a feasible alternative to biogas generation and suggested that optimum conditions for anaerobic co-digestion must be investigated as well as treatment of sludge to manage the landfill crisis. The study revealed further that cow dung and poultry waste as animal waste has great potentials for generation of biogas and its use should be encouraged due to its early retention time and high volume of biogas yields. It has been found that temperature variation, $\mathrm{pH}$ and concentration of total solid etc., are some of the factors that affected the volume yield of biogas production.

\section{References}

Attila Meggyes. Biogas and Energy Production by Utilization of Different Agricultural Wastes. Acta Polytechnica Hungarica. Vol. 9, No. 6, 2012- 65.

Iscia, A., and G.N. Demirerb. Biogas production potential from cotton wastes. Renewable Energy 32 (2007) 750-757

Laboya, I.R., F.F. Asekhame, M.O. Ezugwu, A.A. Erameh and F.E. Omofuma. Studies on Biogas Generation from Agricultural Waste; Analysis of the Effects of Alkaline on Gas Generation. World Applied Sciences Journal 9 (5): 537-545, 2010 ISSN 1818-4952

Laxman Lama, Sunil Prasad Lohani, Ram Lama, and Jhalak Raj Adhikari. Production of biogas from kitchen waste. Rentech Symposium Compendium, Volume 2, December 2012.

Md. ForhadIbne Al Imam, M. Z. H. Khan, M. A. R. Sarkarand S. M. Ali. Development of Biogas Processing from Cow dung, Poultry waste, and Water Hyacinth. International Journal 
of Natural and Applied Science 2013; 2(1): $13-17$

Mohan S and Jagadeesan K. Production of Biogas by Using Food Waste. International Journal of Engineering Research and Applications. 2013.

Nabila Laskri and Nawel Nedjah. Comparative Study for Biogas Production from Different Wastes। International Journal of Bio-Science and Bio-TechnologyVol.7, No.4 (2015), pp.39-46

Navjot Riar, Khitoliya RK and Shakti Kumar. A Study of Tretability of Kitchen Wet Waste and Biogas Production. International Journal of Computational Engineering Research 2012; 3.

Rama Dhanariya*, Sarita Sharma, Ashok K Sharma and Sanjay Verma. A Review on Biogas Production from Food Waste. International journal of pharmaceutical and chemical sciences. Vol. 3 (4) OctDec 2014 www.ijpcsonline

Ravi, P., Agrahariland G. N. Tiwari2.The Production of Biogas Using Kitchen
Waste International Journal of Energy Science (IJES) Volume 3 Issue 6, December 2013 doi: 10.14355/ijes.2013.0306.05.

Sangeetha, P.A., Atharsha, S., Saranyaa Sri. Comparison of Viability of Biogas from Poultry Waste and Mixture of Poultry and Fish Waste.International Journal of Innovative Research in Technology \& Science (IJIRTS) ISSN: 2321-1156

Suyog vij. Biogas production from kitchen waste. Department of Biotechnology and Medical Engineering, National Institute of Technology, Rourkela. 2010-2011.

Tsunatu D. Yavini, Kiman Silas, Mustapha B. Grema and Jang A. Luria. Kinetic Study of Agricultural Wastes Conversion to Biogas using Cow Dung/Poultry Droppings as Inoculums IOSR Journal Of Environmental Science, Toxicology And Food Technology (IOSRJESTFT)Volume 8, Issue 1 Ver. IV (Feb. 2014), PP 46-5 www.iosrjournals.org

\section{How to cite this article:}

Dere, A.J., S.R. Kalbande and Khambalkar, V.P. 2017. Recent Review on Biogas Production from Different Waste. Int.J.Curr.Microbiol.App.Sci. 6(10): 3452-3457. doi: https://doi.org/10.20546/ijcmas.2017.610.407 